\title{
ANALYSIS OF FRACTIONAL-ORDER MODEL OF COVID-19 PANDEMICS WITH A NONLINEAR INCIDENCE RATE
}

\author{
V. Varghese ${ }^{1^{*}}$, S. Bhoyar ${ }^{2}$, K. S. Nisar ${ }^{3}$ \\ ${ }^{1}$ Smt. Sushilabai Bharti Science College, Arni, Yavatmal, India \\ ${ }^{2}$ M. G. College, Armori, Gadchiroli, India \\ ${ }^{3}$ College of Arts and Science, Prince Sattam bin Abdulaziz University, Wadi Aldawaser, Saudi Arabia \\ *Corresponding author: vino7997@gmail.com
}

Received 25 June 2020; Accepted 11 September 2020

\begin{abstract}
Background. Several mathematical representations of contagious disease COVID-19 were evolved in order to capture the pragmatic aspect of unfurling of the disease. It is learned that individuals who became receptive were infected with a rate proportional to the fraction of the individuals affected by the infection, in the comprehensive population as well as the infected individuals recuperate at a sustained rate. It is also observed that in the SIR model, all contacts impart the disease with an identical probability.

Objective. We will estimate the dynamic epidemic behaviour of inflected population for India with the use of fractional-order SIR simulations and compare our results with the results obtained for extrapolated actual cases of the infected people.

Methods. We have obtained the approximate solutions of the fractional-order Susceptible-InfectiousRecovered model within the framework of the modified Riemann-Liouville fractional differential operator using a new iterative fractional complex transform technique.

Results. The optimal values of the fractional-order SIR model parameters were identified with the use of the New Iterative Method. The dynamic incident rate with high and low reproduction number is predicted as well as the illustrated graphical with actual data is provided. To sum, the fractional calculus model for a complex system proposed here is just an indication to show what might happen if we do not control the reproduction number in the community.

Conclusions. The control measures that have already been found like swift surveillance, quarantine and social distancing means, such as face masks and closures, assisted in curtailing coronavirus transmission - estimated by the average number of people each infected individual infects, or reproduction number, to close to the level of 1 in each month.
\end{abstract}

Keywords: SIR-modeling; modified Riemann-Liouville fractional operator; numerical simulations; COVID-19 outbreak; basic reproduction number.

\section{Introduction}

China was the initially infected nation; the behaviour of a novel coronavirus (COVID-19) is distinct from that of the rest of the world. The health care sector has not been prepared for the pandemic; in fact, before some cases were identified, no one was aware of the virus. Moreover, in a considerable short time, China government took strong contentious steps and, although the virus remains widespread, they were able to contain the increasing infections. Thus, the study of pandemic dynamic evolution has been a centre of attraction in recent times. Several mathematical representations of contagious disease were evolved in order to capture the pragmatic aspect of unfurling of the disease $[1-5]$. It is learned from the above reference that individuals who became receptive were infected with a rate proportional to the fraction of the individuals affected by the infection, in the comprehensive population as well as the infected individuals recuperate at a sustained rate. It is also observed that in the SIR model, all contacts impart the disease with an identical probability.

Mostly in SIR model, the mathematical functions used are in the form of an ordinary derivative. In many cases, however, the classical derivative is not able to describe precisely these complex phenomena. With this aim, many researchers try to model as well as to analyze the dynamic behaviour of these nonlinear systems by means of fractional calculus. These fractional operators may mould more adeptly precise real-world circumstance, specifically when the dynamics are affected by constraints inherent to the system. There exist several definitions for fractional derivatives and fractional integrals like the Riemann-Liouville, Caputo, Hadamard, Riesz, Griinwald-Letnikov [6-9]. In 
recent times, the notion of fractional-order derivatives has gained significance because they kept a few of the properties of ordinary derivatives. There is a lot of ongoing research where fractional-order derivatives mathematical models have been fabricated to predict the transmission dynamics in future.

Of most recent literature, some authors have accepted the work on the fractional-order model, which can be summarized as given below. Angstmann et al. [10, 11] considered the fractional-order infectivity as well as recovery SIR epidemic model for dynamical analysis and obtained numerical simulations using the Generalized Euler Method. Hamdan and Kilicman [12] studied the dynamical behaviour of a virus dynamics model with general incidence rate and cure rate for dengue transmission. Mouaouine et al. [13] studied the vigorous deportment of a virus dynamics model with broad occurrence rate and cure rate. Wang et al. [14] presented the delayed fractional-order SIR (susceptible and removed) epidemic model with saturated incidence and treatment functions. Sene [15] considered the SIR epidemic model with some hold up in the situation of the fractional derivative with Mittag-Leffler kernel, and graphically illustrated the approximate solutions of the model. Shaikh et al. [16] estimated the outbreak of disease and potential control strategies using mathematical models using iterative fractional complex transform method to find approximate solutions of the model having modified Riemann-Liouville fractional differential operator. Recently, Nesteruk [26] used the classical SIR model to obtain an exact solution of complex pandemic characteristics for the United States, Germany, the United Kingdom, the Republic of Korea and the world using SIR simulations to compare them with previous results.

In this article, we aim to introduce fractional calculus for modeling the complex systems, especially the SIR epidemic model. Firstly, we briefly discussed the basic fractional derivatives in the preliminary section; and, secondly, the formulation of the fractional-order model of pandemics with a nonlinear incidence rate. Thirdly, modified new iterative fractional complex transform technique suiting our model is obtained. Finally, we present an approach to predict the dynamic incident rate with high and low reproduction number as well as the illustrated graphical with actual data. To sum, the fractional calculus model for a complex system proposed here is just an indication to show what might happen if we do not control the reproduction number in the community.

\section{Preliminaries}

Firstly, this paper describes the Caputo derivative and many lemmas required.

Definition 2.1 The Riemann-Liouville derivative [17-19] of an order $\alpha$ of an arbitrary function $f(t) \in C^{n}\left(\left[t_{0},+\infty\right), \mathrm{R}\right)$ is specified as

$$
D_{t}^{\alpha} f(t)=\frac{1}{\Gamma(n-\alpha)} \frac{d^{n}}{d t^{n}} \int_{t_{0}}^{t}(t-\tau)^{n-\alpha-1} f(\tau) d \tau
$$

where $t_{0}>t, \quad D_{t}^{\alpha}$ denotes the Riemann-Liouville of order $\alpha, \Gamma($.$) is the Gamma function, n$ is the first integer which is greater than $\alpha$, and $\alpha$ is the positive integer such that $n-1<\alpha<n$. If $0<\alpha<1$, then one obtains

$$
D_{t}^{\alpha} f(t)=\frac{1}{\Gamma(1-\alpha)} \int_{t_{0}}^{t} \frac{f(\tau)}{(t-\tau)^{\alpha}} d \tau
$$

Definition 2.2 The Riemann-Liouville integral of an order $\alpha$ is defined as

$$
I_{t}^{\alpha} f(t)=\frac{1}{\Gamma(\alpha)} \int_{t_{0}}^{t}(t-\tau)^{\alpha-1} f(\tau) d \tau, \alpha \in(-\infty, \infty)
$$

Definition 2.3 An alternative explanation of the fractional derivative was proposed by Caputo [6] as

$$
\begin{gathered}
D_{t}^{\alpha} f(t)=J^{n-\alpha} D^{\alpha} f(t) \\
\frac{1}{\Gamma(n-\alpha)} \int_{t_{0}}^{t}(t-\tau)^{n-\alpha-1} \frac{d^{n} f(\tau)}{d \tau^{n}} d \tau, n-1<\alpha<n, \\
\frac{d^{n} f(t)}{d t^{n}}, \alpha=n .
\end{gathered}
$$

The Caputo fractional derivative is a uniformity emerging in the time genesis for the RiemannLiouville fractional derivative by assimilating the pertinent initial circumstances [20]. With precaution taken, the results achieved using the Caputo formulation can be re-modeled to the RiemannLiouville version.

Definition 2.4 Jumarie [21] has proposed an alternate definition as modified Riemann-Liouville derivative by the expression

$$
D_{t}^{\alpha} f(t)=\frac{1}{\Gamma(n-\alpha)} \frac{d^{n}}{d t^{n}} \int_{t_{0}}^{t}(t-\tau)^{n-\alpha-1}[f(\tau)-f(0)] d \tau .
$$




\section{Formulation of the model}

The complex behaviour of the infectious diseases in the classical susceptible-infected-recuperated model (SIR), developed by Kermack and McKendrick [1] as

$$
\begin{gathered}
\dot{S}(t)=-r S(t) I(t), \dot{I}(t) \\
=r S(t) I(t)-\gamma I(t), \dot{R}(t)=\vartheta \gamma I(t)
\end{gathered}
$$

in which three human epidemiological conditions are (i) $S(t)$ susceptible (number of people capable of transmitting the virus) at the time $t$, (ii) $I(t)$ infected (individuals that are contagious and capable of spreading the virus to others) at the time $t$, and (iii) $R(t)$ describe the recuperated/removed (individuals that have been infectious. Here $r=\beta / N$ is the average number of contacts per infective per day, $\beta$ is the contact rate, $N=S+I+R$ is the population size, $1 / \gamma$ is the mean infectious period, thus $\gamma$ is the recovery rate, $\vartheta$ denotes the fraction of infectious individuals who recover from the disease; thus the fraction $(1-\vartheta)$ dies from the disease, and the prime (. ) in equations denotes differentiation with respect to the variable time $t$, respectively.

The flow diagram for the disease dynamics with compartments $S, I$ and $R$ are given in Fig. 1 .

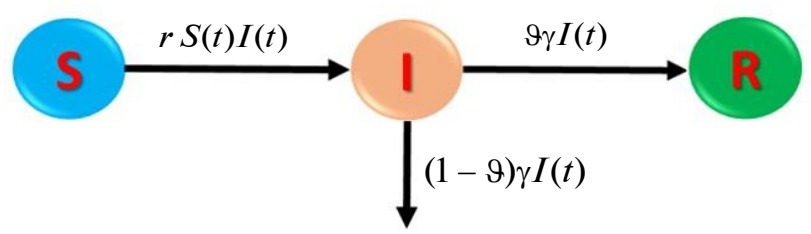

Figure 1: Flow diagram of the SIR model

By using fractional Caputo derivative of order $\alpha$ on either side of each Eq. (6), and assuming the certainty that Caputo fractional derivative and fractional integral are operating inversely, the following fractional differential equation can be achieved for SIR model as

$$
\begin{gathered}
D_{t}^{\alpha} S(t)=-r S(t) I(t), D_{t}^{\alpha} I(t) \\
=r S(t) I(t)-\gamma I(t), D_{t}^{\alpha} R(t)=\vartheta \gamma I(t) .
\end{gathered}
$$

To transform the differential equation given by $f\left(u, u_{t}^{(\alpha)}, u_{t}^{(2 \alpha)}, \ldots\right)=0, u_{t}^{(\alpha)}=d^{\alpha} u(t) / d t^{\alpha}, \quad 0<\alpha \leq 1$ in non-integer form into an ordinary differential equation, introducing a complex variable [22], and using the basic properties of the fractional derivative given in Eq. (5), one obtains

$$
\xi=\frac{q t^{\alpha}}{\Gamma(1+\alpha)} \Rightarrow \frac{d^{\alpha} u}{d t^{\alpha}}=q \frac{d u}{d \xi}
$$

in which $q$ is constant (which will be determined later) and $u_{t}^{\alpha}$ represents modified Riemann-Liouville derivatives.

Substituting Eq. (8) in Eq. (7), one obtains the system of equations as

$$
\begin{gathered}
S^{\prime}(\xi)=-\frac{1}{q}[r S(\xi) I(\xi)], \\
I^{\prime}(\xi)=\frac{1}{q}[r S(\xi) I(\xi)-\gamma I(\xi)], \\
R^{\prime}(\xi)=\frac{1}{q}[\vartheta \gamma I(\xi)]
\end{gathered}
$$

with initial conditions

$$
S(0)=S_{0}>0, I(0)=I_{0}>0, R(0)=R_{0} \geq 0,0<\alpha \leq 1
$$

in which the prime (' $)$ in equations denotes differentiation with respect to the variable time $\xi$.

From the initial conditions, the disease-free equilibrium is obtained as $(S, I, R)=\left(S_{0}, 0,0\right)$. Thus, focusing on the second equation of Eq. (9), one obtains the threshold between the disease dying out or causing a pandemic as $\mathfrak{A}_{0}=r S_{0} / \gamma=1$. From the dynamics of the system, if $\mathfrak{A}_{0}<1$, then the infectious individuals decreases monotonically to zero, whereas if $\mathfrak{A}_{0}>1$ then the infection will be spreading in a population before tending to zero.

If we consider the natural death rate as $d>0$, then the equation for the infectious individual is expressed as

$$
I^{\prime}(\xi)=\frac{1}{q}[r S(\xi) I(\xi)-(d+\gamma) I(\xi)]
$$

which provides the basic reproduction number $\left(\mathfrak{A}_{0}\right)$ for the model as

$$
\mathfrak{A}_{0}=\frac{r S(0)}{(d+\gamma)}, \quad S(0)=\frac{A}{d}
$$

where $A>0$ is the susceptible individual per unit time.

In order to solve Eqs. (10) and (12), a new iterative technique can also be considered, which has been framed in the later sections. 


\section{Extended 'New iterative method'}

Consider the nonlinear equation

$$
y_{i}(t)=N_{i}\left(y_{1}(t), y_{2}(t), \ldots, y_{n}(t)\right)+c, i=1,2, \ldots, n
$$

in which $N_{i}$ is a nonlinear operator.

We assume the solution of Eq. (13) in the following series form

$$
y=y_{i}(t)=\sum_{j=0}^{k} y_{i, j}(t), i=1,2 \ldots, n .
$$

The nonlinear operator $N_{i}$ can be decomposed [23] as

$$
\begin{gathered}
N_{i}(y)=N_{i}\left(y_{0}\right) \\
+\sum_{i=1}^{n}\left\{N_{i}\left(\sum_{j=0}^{k} y_{j}(t)\right)-N_{i}\left(\sum_{j=0}^{k-1} y_{j}(t)\right)\right\} .
\end{gathered}
$$
yields

Substituting Eqs. (14) and (15) into Eq. (13)

$$
\begin{gathered}
\sum_{i=0}^{\infty} y_{i, j}(t)=c+N_{i}\left(y_{0}(t)\right) \\
+\sum_{i=1}^{n}\left\{N_{i}\left(\sum_{j=0}^{k} y_{j}(t)\right)-N_{i}\left(\sum_{j=0}^{k-1} y_{j}(t)\right)\right\} .
\end{gathered}
$$

We define the recurrence relation as

$$
\begin{aligned}
& y_{0}=y_{i, 0}(t)=c, \\
& y_{1}=y_{i, 1}(t)=N_{i}\left(y_{0}(t)\right), \\
& y_{2}=y_{i, 2}(t)=N_{i}\left(y_{0}(t)+y_{1}(t)\right)-N_{i}\left(y_{0}(t)\right), \\
& \vdots \\
& y_{m+1}=y_{i, m+1}(t)=N_{i}\left(y_{0}(t)+y_{1}(t)+\ldots+y_{m}(t)\right) \\
& -N_{i}\left(y_{0}(t)+y_{1}(t)+\ldots+y_{m-1}(t)\right) \text {. }
\end{aligned}
$$

The $k-$ term series solution is given as

$$
\begin{gathered}
y_{i}=y_{0}+y_{1}+\ldots+y_{m+1} \\
=N_{i}\left(y_{0}(t)+y_{1}(t)+\ldots+y_{m}(t)\right), m=1,2 \ldots
\end{gathered}
$$

To check the convergence status of Eq. (58), we consider the proof by contradiction [24], i.e. $\left\|N_{i}(x)-N_{i}(y)\right\| \leq K\|x-y\|, 0<K<1$, then

$$
\begin{gathered}
\left\|y_{m+1}\right\|=\| N_{i}\left(y_{0}+y_{1}+\ldots+y_{m}\right) \\
-N_{i}\left(y_{0}+y_{1}+\ldots+y_{m-1}\right) \| \\
\leq\left\|N_{i}(x)-N_{i}(y)\right\| \\
\leq K\left\|y_{m}\right\| \leq K^{m}\left\|y_{0}\right\|, m=0,1,2 \ldots
\end{gathered}
$$

and the series $\sum_{i=0}^{\infty} y_{i}$ absolutely and uniformly converges to a solution of Eq. (1).

\section{Forecast of pandemics}

In this section, by using the extended New Iterative Method (NIM) as given in Eq. (18), which is a modified technique of Daftardar-Gejji and Jafari method (DGJ) is applied for data fitting, numerical stimulation and graphical demonstration of the Caputo COVID-19 model given in Eq. (9) for the population of India and some most infected state. The data pertaining to our study is available on websites of the public health authority. Firstly the basic reproductive number $\mathfrak{A}_{0}$ for our model can be directly generated by one individual in a population. By applying the iterative fractional complex transform using Eqs. (8) and (17), we get series form approximate solution of the fractional model as given in Eq. (7) as given below

$$
\begin{gathered}
S\left(t_{i+1}\right)=S\left(t_{i}\right) \\
+\sum_{j=1}^{k} \frac{t^{j \alpha}}{\Gamma(1+\alpha)^{j}}\left\{\left[-r S\left(t_{i+1}\right) I\left(t_{i+1}\right)\right]-\left[-r S\left(t_{i}\right) I\left(t_{i}\right)\right]\right\}, \\
I\left(t_{i+1}\right)=I\left(t_{i}\right) \\
+\sum_{j=1}^{k} \frac{t^{j \alpha}}{\Gamma(1+\alpha)^{j}}\left\{\left[r S\left(t_{i+1}\right) I\left(t_{i+1}\right)-\gamma I\left(t_{i+1}\right)\right]\right. \\
\left.-\left[r S\left(t_{i}\right) I\left(t_{i}\right)-\gamma I\left(t_{i}\right)\right]\right\}, \\
R\left(t_{i+1}\right)=R\left(t_{i}\right) \\
+\sum_{j=1}^{k} \frac{t^{j \alpha}}{\Gamma(1+\alpha)^{j}}\left\{\left[\vartheta \gamma I\left(t_{i+1}\right)\right]-\left[\vartheta \gamma I\left(t_{i}\right)\right]\right\} .
\end{gathered}
$$

Now, we consider our model from the $t=0$ as per data with the initial first case of susceptible reported on $30^{\text {th }}$ January 2020, and upto the maximum number of infected cases in total in India [25] as on $29^{\text {th }}$ August 2020 for analysis and simulation. Hence the required initial values are taken as $S(0)=1380004385, I(0)=1, R(0)=0$. The other parameters were estimated based on assumptions and facts such as the Death rate $(d)$ is set to 7.23 deaths per 1000 people, median estimate of the Incubation period is set to 5.5 days, Contact Rate $(\beta)$ is 19.29 , Transmissibility is set as $2.0 \%$, and the duration of Infectiousness is 11 days. For the mathematical calculation of the dynamical behaviour of the infected population, we consider the high and low value of reproduction number $\left(\mathfrak{A}_{0}\right)$ for our model as 3.86 and 1.16 
respectively for different value of fractional order $\alpha=0.6,0.7,0.8,0.9,1$ with respect to time (in Days).

Similarly, based on historical data if we take the nonlinear algebraic using a best fit polynomial curve of order 5 as

$$
\begin{gathered}
y(t)=-0.0002 t^{5}+35.041 t^{4}-3 \times 10^{6} t^{3} \\
+1 \times 10^{11} t^{2}-3 \times 10^{15} t+3 \times 10^{15}, R^{2}=99.97 \%
\end{gathered}
$$

where $R^{2}$ is the co-efficient of determination.

Now taking $y_{0}=0$ and $N\left(y_{0}(t)\right)<0$, we can employ the algorithm given in Eq. (17) to get the solution as follows

$$
\begin{aligned}
& y_{0}=1, \quad y_{m+1}=N\left(y_{0}+y_{1}+\ldots+y_{m}\right) \\
& -N\left(y_{0}+y_{1}+\ldots+y_{m-1}\right), m=1,2, \ldots .
\end{aligned}
$$

Hence, we can quickly obtain extrapolated historical data for our comparative analysis using Eq. (21).

Classical SIR model $(\alpha=1)$ : The values in Table 1 illustrates the complete scenario of the estimated results of infected populations for $\alpha=1$ order. Fig. 2 depicts the moving average and growth rate in new cases per day of the inflected community along time for classical SIR model to predicting the developmental pattern of the disease situation and promoting the decision-making mechanisms for infection prevention. Fig. 3 shows the historical behaviour of new cases per day along time shows an exponential enhancement in infected patients.

Table 1: Indian epidemic features based on classical SIR model

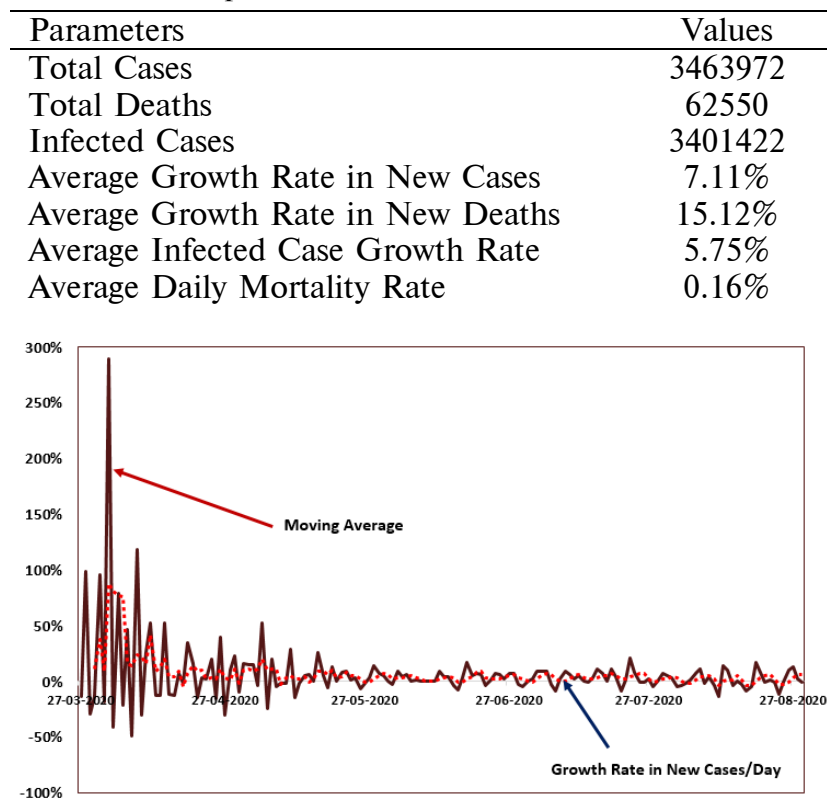

Figure 2: Moving average and growth rate in new cases per day of inflected population along time for $\alpha=1$

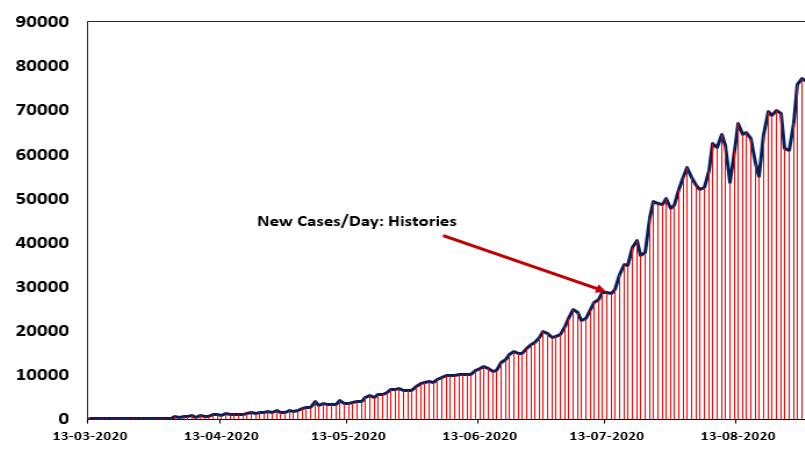

Figure 3: Historical behaviour of new cases per day along time for $\alpha=1$

Fractional-order SIR model $(0<\alpha \leq 1)$ : Figs. 4 and 5 show the dynamical behaviour of inflected population along time (in days) for various values of $\alpha$ for a fixed low $\mathfrak{A}_{0}=1.16$ and high $\mathfrak{A}_{0}=3.86$, for different values of $\alpha=0.6,0.7,0.8$, 0.9 , 1. It is observed that with the lowering of reproduction number $\mathfrak{A}_{0}$ the population of infected cases along the period after a saturation point decreases monotonically towards zero. The fractional model makes, depending on the system parameters, both a disease-free and an infectious, long-term equilibrium state.

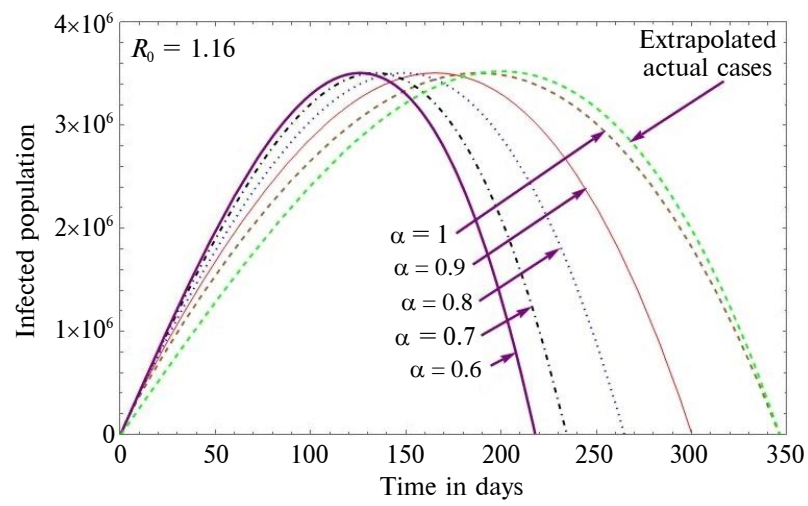

Figure 4: Dynamical behaviour of inflected population along time for various values of $\alpha$ and fixed $\mathfrak{A}_{0}=1.16$

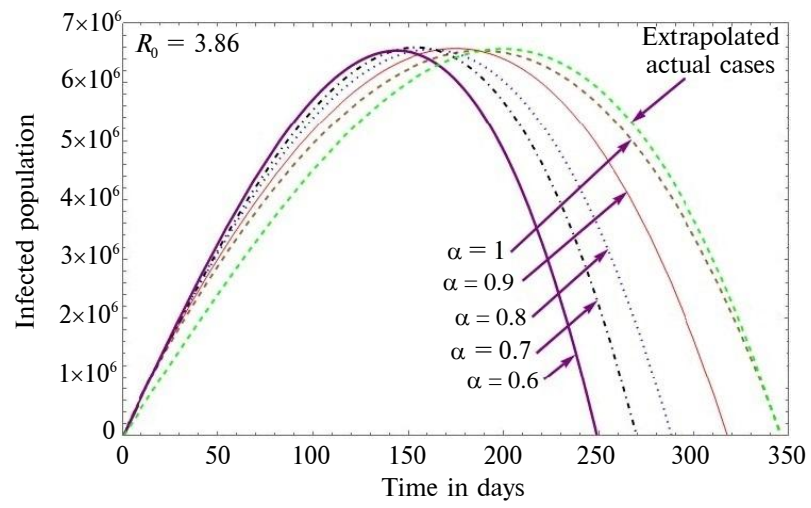

Figure 5: Dynamical behaviour of inflected population along time for various values of $\alpha$ and fixed $\mathfrak{A}_{0}=3.86$ 
From Table 2, it is seen that with the decrease of the fractional parameter value $\alpha$, the infected case also reduces with respect to time (in days). Thus, it is observed that reducing the contact rate by increasing the quarantined period, social distancing, and restricting the migration can reduce the seriousness of pandemic effectively, and flattening of cure of infection will nearly take a year of time.

Table 2: Comparative study of extrapolated and calculated figures of inflected population

\begin{tabular}{cccc}
\hline $\begin{array}{c}\text { Reproduction } \\
\text { number }\end{array}$ & $\begin{array}{c}\text { Estimated } \\
\text { details }\end{array}$ & $\begin{array}{c}\text { No. } \\
\text { of } \\
\text { days }\end{array}$ & $\begin{array}{c}\text { Inflected } \\
\text { population } \\
\text { in Nos. }\end{array}$ \\
\hline \multirow{2}{*}{3.86} & Extrapolated & 203 & 6559000 \\
& Calculated & 200 & 6559000 \\
1.16 & Extrapolated & 203 & 3580000 \\
& Calculated & 192 & 3499000
\end{tabular}

\section{Conclusions}

In this article, we have obtained the approximate solutions of the fractional-order SusceptibleInfectious-Recovered model within the framework of the modified Riemann-Liouville fractional differential operator. The estimated results and actual cases of the infected population are computed using a new iterative fractional complex transform technique by reducing the computation steps and illustrated graphically. Again, without the availability of vaccine or effective treatment, ceasing transmission is the only defence against COVID-19. Realizing the consequences of each control measure is essential to understand the ones that can be safely changed or detached. A comparative analysis with some of the highly infected countries shows that if preventive steps such as quarantine and urban sanitation are strictly implemented, India can still control the situation. The forecasting models would help prepare the government and medical workforce for future scenarios to provide greater readiness in health care systems. The control measures that have already been found like swift surveillance, quarantine and social distancing agencies, such as, face masks and closures, assisted in curtailing coronavirus transmission - estimated by the average number of people each infected individual infects, or reproduction number to close to the level of 1 in each month. Moreover, incorporating data from around the world will allow the researchers to compare individual countries for the best design fractional-order SIR model that can make more accurate predictions about new phases of the pandemic and analyze transmission dynamics across many nations. It is recommended that more studies can be conducted with the proposed dynamic model for forecasting outbreaks in other countries.

\section{References}

[1] Kermack WO, McKendrick AG. A contribution to the mathematical theory of epidemics. Proc R Soc A Math Phys Eng Sci. 1927;115:700-21. DOI: 10.1098/rspa.1927.0118

[2] Cooke KL. Stability analysis for a vector disease model. Rocky Mountain J Math. 1979;9(1):31-42. DOI: $10.1216 /$ RMJ-1979-9-1-31

[3] Brauer F, Castillo-Chavez C. Mathematical models in population biology and epidemiology. Texts in Applied Mathematics. New York: Springer; 2012. DOI: 10.1007/978-1-4614-1686-9

[4] Grassly NC, Fraser C. Mathematical models of infectious disease transmission. Nat Rev Microbiol. 2008;6(6):477-87. DOI: $10.1038 /$ nrmicro1845

[5] Vitanov NV, Ausloos MR. Knowledge epidemics and population dynamics models for describing idea diffusion. arXiv [Preprint] 2012. Available from: arXiv:1201.0676v1

[6] Caputo M. Linear models of dissipation whose Q is almost frequency independent-II. Geophys J Int. 1967;13(5):529-39.

[7] Podlubny I. Fractional differential equations. New York: Academic Press; 1999.

[8] Diethelm K. The analysis of fractional differential equations: an application-oriented exposition using operators of Caputo type. Springer; 2004.

[9] Kilbas AA, Srivastava HM, Trujillo JJ. Theory and applications of fractional differential equations. Vol. 204. Elsevier Science; 2006.

[10] Angstmann CN, Henry BI, McGann AV. A fractional-order recovery SIR model from a stochastic process. Bull Math Biol. 2016;78(3):468-99. DOI: 10.1007/s11538-016-0151-7

[11] Angstmann CN, Henry BI, McGann AV. A fractional-order infectivity SIR model. Phys A Stat Mech Appl. 2016;452:86-93. DOI: $10.1016 /$ j.physa.2016.02.029

[12] Hamdan NI, Kilicman A. A fractional-order SIR epidemic model for dengue transmission. Chaos Solitons Fractal. 2018;114:55-62. DOI: 10.1016/j.chaos.2018.06.031 
[13] Mouaouine A, Boukhouima A, Hattaf K, Yousfi N. A fractional-order SIR epidemic model with nonlinear incidence rate. Adv Differ Equ. 2018;1:160. DOI: 10.1186/s13662-018-1613-Z

[14] Wang X, Wang Z, Huang X, Li Y. Dynamic analysis of a delayed fractional-order SIR model with saturated incidence and treatment functions. Int J ifurcation Chaos. 2018;28(14):1850180. DOI: 10.1142/S0218127418501808

[15] Sene N. SIR epidemic model with Mittag-Leffler fractional derivative. Chaos Solitons Fractals. 2020;137:109833. DOI: $10.1016 /$ j.chaos.2020.109833

[16] Shaikh AS, Jadhav VS, Timol MG, Nisar KS, Khan I. Analysis of the COVID-19 pandemic spreading in India by an epidemiological model and fractional differential operator. Preprints [Preprint] 2020. preprint. DOI: 10.20944/preprints202005.0266.v1

[17] Oldham KB, Spanier J. The Fractional calculus. New York: Academic Press; 1974.

[18] Samko SG, Kilbas AA, Marichev OI. Fractional integrals and derivatives: Theory and applications. Gordon and Breach Science Publishers; 1993.

[19] Miller KS, Ross B. An Introduction to the fractional calculus and fractional differential equation. New York: Wiley; 1993.

[20] Gorenflo R, Mainardi F. Fractional calculus: integral and differential equations of fractional order. In: Carpineti A, Mainardi F, editors. Fractals and fractional calculus in coninum mechanics. Vienna: Springer; 1997.

[21] Jumarie G. Modified Riemann-Liouville derivative and fractional Taylor series of nondifferentiable functions further results. Comput Math Appl. 2006;51(9-10):1367-76. DOI: 10.1016/j.camwa.2006.02.001

[22] Li ZB, He JH. Fractional complex transform for fractional differential equations. Math Comput Appl. 2010; 15:970-973.

[23] Daftardar-Gejji V, Jafari H. An iterative method for solving nonlinear functional equations. J Math Anal Appl. 2006;316:753-63.

[24] Bhalekar S, Daftardar-Gejji V. Convergence of the new iterative method. Int J Diff Eq. 2011;2011:989065. DOI: $10.1155 / 2011 / 989065$

[25] Ministry of Health and Family Welfare, Govt. of India [Internet]. Mohfw.gov.in. 2020 [cited 2020 May 31]. Available from: https://www.mohfw.gov.in/

[26] Nesteruk I. Simulations and predictions of COVID-19 pandemic with the use of SIR model. Innov Biosyst Bioeng. 2020;4(2):110-21. DOI: 10.20535/ibb.2020.4.2.204274

\section{В. Варгезе, С. Бхояр, К.С. Нiсар}

\section{АНАЛІЗ МОДЕЛІ ДРОБОВОГО ПОРЯДКУ ДЛЯ ПАНДЕМІЇ COVID-19 І3 НЕЛІНІЙНОЮ ЧАСТОТОЮ ЗАХВОРЮВАНОСТІ}

Проблематика. Кілька математичних моделей інфекційного захворювання COVID-19 були розроблені для того, щоб відобразити практичний аспект поширення цього захворювання. Встановлено, що люди, які стали вразливими до вірусу, інфікувалися зі швидкістю, пропорційною частці людей, уражених інфекцією, серед загального населення, а також що швидкість одужання інфікованих людей є постійною. Відзначається, що в SIR-моделі всі контактні особи можуть передати хворобу з однаковою ймовірністю.

Мета. Ми оцінюємо динаміку епідемічної поведінки інфікованого населення Індії з використанням SIR-моделювання дробового порядку та порівнюємо наші результати з результатами, отриманими для екстрапольованих фактичних випадків інфікування людей.

Методика реалізації. Отримано наближені розв'язки SIR-моделі дробового порядку в межах модифікованого дробоводиференціального оператора Рімана-Ліувілля з використанням нового ітераційного методу дробового комплексного перетворення.

Результати. За допомогою нового ітераційного методу встановлено оптимальні значення параметрів SIR-моделі дробового порядку. Спрогнозовано динамічну частоту випадків із високим і низьким числом відтворень, а також наводиться ілюстрований графік із фактичними даними. Відзначимо, що пропонована нами модель дробового обчислення для складної системи є лише показником того, що може статися, якщо ми не будемо контролювати число вторинних випадків зараження, викликаних однією інфікованою людиною, в позалікарняних умовах.

Висновки. Уже встановлені заходи контролю, такі як оперативне спостереження, карантин і заходи соціального дистанціювання, наприклад маски для обличчя і обмеження в роботі різних закладів, допомогли обмежити передачу коронавірусу, що оцінюється за середньою кількістю людей, які заражаються одним інфікованим, тобто за репродукційним числом, що досягає приблизно 1 у кожен місяць.

Ключові слова: SIR-моделювання; модифікований дробовий оператор Рімана-Ліувілля; числове моделювання; спалах COVID-19; базове репродукційне число.

\section{В. Варгезе, С. Бхояр, К.С. Нисар}

\section{АНАЛИЗ МОДЕЛИ ДРОБНОГО ПОРЯДКА ДЛЯ ПАНДЕМИИ COVID-19 С НЕЛИНЕЙНОЙ ЧАСТОТОЙ ЗАБОЛЕВАЕМОСТИ}

Проблематика. Несколько математических моделей инфекционного заболевания COVID-19 были разработаны для того, чтобы отобразить практический аспект распространения этого заболевания. Установлено, что люди, которые стали восприимчивыми к вирусу, инфицировались со скоростью, пропорциональной доле людей, пораженных инфекцией, среди общего населения, а также что скорость выздоравливания инфицированных людей является постоянной. Отмечается, что в SIR-модели все контактные лица могут передать болезнь с одинаковой вероятностью. 
Цель. Мы оцениваем динамику эпидемического поведения инфицированного населения Индии с использованием SIRмоделирования дробного порядка и сравниваем наши результаты с результатами, полученными для экстраполированных фактических случаев инфицирования людей.

Методика реализации. Получены приближенные решения SIR-модели дробного порядка в рамках модифицированного дробно-дифференциального оператора Римана-Лиувилля с использованием нового итерационного метода дробного комплексного преобразования.

Результаты. C помощью нового итерационного метода определены оптимальные значения параметров SIR-модели дробного порядка. Спрогнозирована динамическая частота случаев с высоким и низким числом воспроизведений, а также приводится иллюстрированный график с фрактическими данными. Отметим, что предлагаемая нами модель дробного исчисления для сложной системы является лишь показателем того, что может произойти, если мы не будем контролировать число вторичных случаев заражения, вызванных одним инфицированным человеком, во внебольничных условиях.

Выводы. Уже установленные меры контроля, такие как оперативное наблюдение, карантин и меры социального дистанцирования, например маски для лица и ограничения в работе различных заведений, помогли ограничить передачу коронавируса, которая оценивается по среднему количеству людей, заражаемых одним инфицированным, то есть по репродуктивному числу, достигающему приблизительно 1 в каждый месяц.

Ключевые слова: SIR-моделирование; модифицированный дробный оператор Римана-Лиувилля; численное моделирование; вспышка COVID-19; базовое репродуктивное число. 